\title{
CLIL Audio Materials: A Speaking Model for Library Science Department Students
}

\author{
https://doi.org/10.3991/ijet.v15i07.13223 \\ Nur Mukminatien, Rahmati Putri Yaniafari ( $\left.{ }^{\bowtie}\right)$, Taufik Kurniawan, \\ Agung Wiradimadja \\ Universitas Negeri Malang, Malang, Indonesia \\ yaniafari.fseum.ac.id
}

\begin{abstract}
To respond to the need of suitable materials for students of Library Science Department of Universitas Negeri Malang, this R\&D project was designed to produce audio speaking materials using CLIL approach for blended learning. The method of development covered three main stages: exploring (identification and exploration of needs), developing (pedagogical realization of the product), and validating using peer review, practitioners' validation, media expert validation, and try out. Three innovations were produced in this study: (1) Competence- CLIL-Based Speaking Syllabus completed with a speaking assessment instrument covering a speaking prompt and a scoring rubric, (2) audio materials accessible through Edmodo, (3) and a module for Speaking activities. The results show that the materials are suitable for the students' communicative needs, interesting and meaningful for them. They also make learners motivated to learn.
\end{abstract}

Keywords - CLIL, ESP, audio material, R \& D, blended learning.

\section{Introduction}

The teaching of English as a compulsory subject in Universitas Negeri Malang (UM), Indonesia, has been directed to develop the students' competence in using English for effective communication for their professional performance and their future life as well. The urgent need is that all UM graduates should have a good command of English to perform effectively in their workplace. As a consequence, the teaching of English should be geared to developing the students' competence in using English for effective communication relevant to their profession. Therefore, providing life-based curriculum, an approach that responds to learners' need for "now and the future" life, is recommended. So far, however, the materials are selected from many different sources in a compilation to meet their professional and life needs supported with teacher-made exercises and tasks, but materials for speaking is limited.

The Library Science Department of UM, established in 2014, needs audio materials for developing students' oral communicative competence. In this program, English is offered in three consecutive semesters. Semester one is focused on Speaking, semester two on Reading, and semester three on Translation. The Speaking course focuses on 
developing students' ability to speak for everyday communication and for professional purposes, while the Reading course is directed to develop students' comprehension of passages relevant to their major, and Translation is focused on developing students' ability in translating short texts from English into Indonesian and vice versa [1]. Observations in the teaching of English and documents in the program indicate that there is no syllabus but merely a course description. The curriculum is in the process of development and is not final yet. Based on an interview with the lecturers of the English courses, the materials for speaking are selected and compiled from many different sources. In addition, the students' final grade is obtained from unstructured assessment procedure since there is no standard assessment available. This might be partly due to the unavailability of an appropriate syllabus and inadequate materials. Usually, the students learn English from print materials combined with some offline digital ones in the form of samples of dialogues recorded from online sources. Such a condition is not sufficient to develop students' oral communicative competence; therefore, relevant and suitable materials are needed.

Considering that technology is now widespread and has been changing the way students learn, it is important to utilize technology in teaching English for learners of different content areas. Dudeney \& Hockly asserts that the use of technology in the classroom is increasingly important [2]. One of the reasons is that using a range of ICT tools to teach English can give learners exposure to authentic language use and make them practice in all of the four language skills. The use of audio-visual media can be done either online or off line. The teacher can down-load movies from you tube and play them in the classroom off line if internet connection is not available.

Teaching English for students of non-English Department needs themes/topics and knowledge of their major so that they can learn language and at the same time learn their subject matter knowledge; so, adopting CLIL (Content Language Integrated Learning) is recommended. This move of language teaching approach has been claimed to be challenging to "bring together the insight of language teaching and a content teaching into a coherent goal" [3]. This approach is basically similar to the previously known as content-based syllabus [4], which refers to teaching English and, at the same time, teaching content knowledge of subject matter areas. CLIL approach, when implemented with blended learning, (BL), a combination of face-to-face and online formats [5], would be a good choice. This is suitable for a situation when classroom meetings are limited while there are many aspects to learn through different kinds of tasks.

Pertaining to the need of combining online and face to face learning experience for the students, multimedia use in language classes is imperative. As a result, the notion of literacy needs to be redefined. The meaning of literacy has been broadened; it does not only refer to the ability to read and write in a conventional way but also in the digital era when technology plays its role that makes it easier for learners learn English independently through multimedia experiences. This has made learning more flexible in terms of time and place. 


\subsection{Multiple media in language learning and literacy}

Obviously, technology has changed the way students learn and broaden the meaning of literacy. Literacy no longer just refers to reading and writing, which means the ability to read and write print texts, but now it has been broadened into both print and nonprint texts. So, literacy education means educating students to become media literate. Media-literate students are those who know how print and non-print texts function together in the development of thought, language, and knowledge. According to Cox (1996:450-451), literacy education makes students learn how to create meaning and communicate effectively through multiple media as stated below.

In a broad view of literacy, students learn to understand and create messages through experiences with many forms of media. Thus, the effective use of non-print media in the classroom means teaching about and with rather than simply through media. Active learning experiences with both print and non-print provide opportunities for students to achieve literacy across multiple media forms.

This emerging modern technology has made teachers aware that information reaches education very fast in many different forms of modality. A reading class for example, when implemented with the support of multiple media forms: visual, audio visual, and print, would provide students with many different experiences to find information that makes them media literate. All skills can be developed in an integrated manner. Combining face-to-face learning and technology-based learning now characterizes the integrated way language is learned in an educational context [6].

Currently, the widespread of technology makes a significant effect on the booming of the productions of ICT-based teacher-made instructional materials by EFL teachers in Indonesian schools such as Listening courseware [7], [8], multimodal texts for comprehension [6], web-based writing media (Silcha, 2016), and many other types of digital materials. The fact shows that Blended Learning (BL) has been implemented by many EFL teachers. A model introduced by Banados shows the benefit of BL when she combined her teaching embracing many different kinds of activities covering

1. Learners' independent work

2. Face-to-face EFL classes where the teacher plays her role as a class teacher and online tutor,

3. Online monitoring for students' progress

4. Weekly conversation with native speakers [9].

Miyazoe \& Anderson investigated the use of three different online writing tasks in university education (forums, blogs, and wikis) employing constructivistic, reflective, and collaborative learning [10]. It showed positive results as indicated by the students' progress in their ability to differentiate English writing styles. It also revealed students' positive perception of the blended course design; they consider it challenging and fun for them to experience.

Based on the need and some evidence of effective BL learning experiences, this study was designed to develop materials for a speaking course for both online and offline face-to face learning. The materials would provide suitable, interesting, and challenging tasks for the learners to develop their speaking. The audio speaking 
materials would be beneficial for students of Library Science Department to prepare them for their professional needs. Also, the materials could be used for in-service training for librarians.

\subsection{Materials development}

For the purpose of providing students with multimedia learning for oral production, materials were prepared in a systematic procedure. The materials were developed based on a syllabus of the course as part of a course design. A course design is an instructional design based on which materials are developed. The materials were developed in a framework comprising several steps:

1. Assessing needs

2. Formulating goals and objectives

3. Developing materials

4. Designing an assessment plan

5. Organizing the course

6. Conceptualizing course content [11].

Based on the design, the syllabus was made, containing a description of all aspects of the planning, implementation, and evaluation of an educational program including the intended experiences of the pupils and the learning organization [12].

After designing the syllabus, the materials were developed by considering the components to cover and accommodating the notion of language proficiency as a multifaceted modality consisting of various levels of ability and domains" [13]. Considering that developing speaking ability means developing students' oral communicative competence, the speaking components were determined based on theories of communicative competence proposed by Canale \& Swain covering grammatical competence, discourse competence, sociolinguistic competence, and strategic competence [14]. Grammatical competence refers to the ability to use linguistic system and the functional aspects of communication, while discourse competence deals with inter-sentential relationships in expressing ideas, or how utterances are linked together coherently to convey meaning. Sociolinguistic competence is the knowledge of appropriateness in communication dealing with what is expected socially and culturally by the users of the language. Strategic competence is the leaners' ability to manipulate language in order to meet communicative goals effectively.

To conclude, this research project was designed for developing audio speaking course materials for students of Library Science Department, which could be used for blended learning format. The content accommodates the theories of communicative competence and the themes/topics of their subject matter area and expertise (as librarians) specifically for their professional needs. The materials could also be used as in-service training for librarians for professional development.

The products of the research and development $(\mathrm{R} \& \mathrm{D})$ are a set of speaking materials containing three kinds of innovation output specified as follows. 
a) A prototype of Competence-Based CLIL Syllabus of Speaking for Librarians. The syllabus provides topics of daily life and conversation related to library activities. Each unit contains information of the online and face-to face activities for the audio materials, including an example of speaking assessment (a speaking prompt and a scoring rubric).

b) Audio materials for Speaking containing 9 Units of theme/situation with language functions mostly in the forms of conversations and a model of topic presentation.

c) A module for Speaking containing examples of expressions for learning grammar and vocabulary exercises. In the module, each unit gives information on which tasks are used in the classroom and which ones are online assignments for speaking practices through Edmodo.

\section{Method}

Based on the underlying theories of material development, this R\&D was carried out using Borg's and Gall's (1987) macro design: Exploring, Developing, Validating, and Implementing. It was combined with the steps adopted from McGrath covering: PreDevelopment, pedagogical realization, and production of final draft [15]. The implementation is specified into more detailed steps as shown in Figure 1. Figure1 shows Borg' \& Gall' macro stages, and the steps were structured into

1. Preliminary investigation (Exploring)

2. Developing the draft

3. Producing the final draft.

Davies's \& Mitchel's steps were done in Stage 1 and Stage 2, while stage 3 was basically the technical realization of the product and validation.

In the last stage, the product try-out, the materials were implemented to target learners' class to identify how they could be used to develop students' speaking skill. Then the results were used as the basis for revision to finalize the product, including the identification of how the materials worked and identified the students' opinion on the implementation of the audio materials. These steps would serve as systematic procedures in developing audio speaking materials.

1. Exploring: Identification, exploration, and contextualization of needs was done by using online questionnaire and was sent to the lecturers and the students to identify what kinds of speaking activities the students need in order to perform an oral communication as a future librarian and to perform daily communication needs. The results could be concluded that learners needed 9 areas of language function and situation: greeting and asking for and giving information, describing a library service, asking for and giving directions, presenting a topic in an international conference, introducing someone, giving and responding to suggestions, making a request, performing a good impression at a job interview, including making a response effectively in a job interview, and casual conversation (meeting people). 
2. Developing the draft started with making a content map, and then followed by developing a syllabus. The syllabus was developed based on the language functions selected by the respondents (students and teachers). The syllabus contains the core materials, and the "learning experience" column contains information on which part of the materials is for face-to-face, and which one is for online learning outside class. Then, scripts for speaking was created, and the conversations were made by recording the conversations performed by senior English Department students as models. The syllabus was supported with a speaking assessment covering a speaking prompt and a scoring rubric. The module was made containing the tasks for practicing a conversation, grammar and vocabulary explanation, and exercises.

3. Technical Realization (validating) was carried out to evaluate the recorded materials and paper-based materials (grammar and vocabulary). An expert in ELT was asked to review and give feedback for the module and audio script while an expert in ICT was asked to review and give feedback for the audio materials.

4. Implementation, the try-out, was conducted to 12 volunteers (students of Library Science Department) but only 8 responses.)

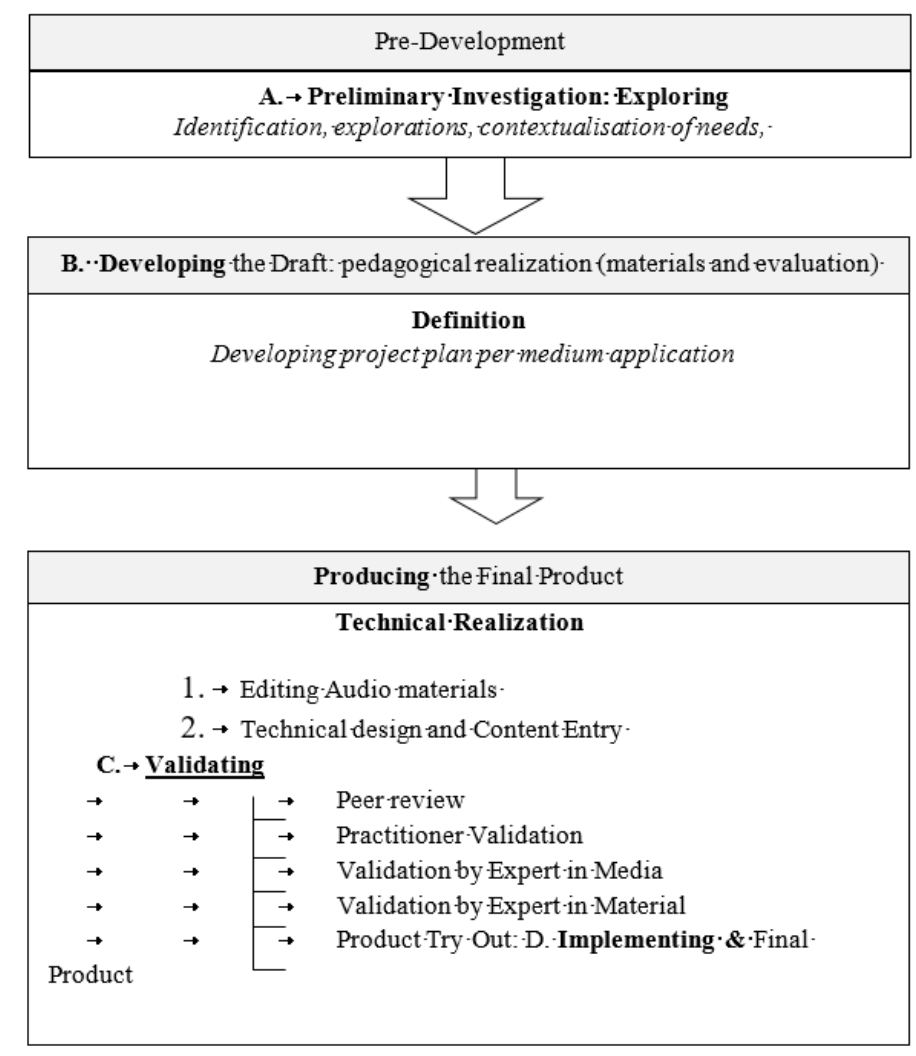

Fig. 1. Procedure of Materials Development 


\section{Results and Discussion}

In the preliminary study to identify the students' English proficiency, a questionnaire was distributed to them. The responses of the questionnaires covered quantitative and qualitative data. The quantitative data were collected to identify their English proficiency, while the qualitative data dealt with their opinion concerning the teaching of English in the Library Science Department.

\subsection{Results}

Based on the quantitative data using scores ranging from 1 (strongly disagree) to 5 (Strongly Agree), their English proficiency is shown in Table 1.

Table 1. Students' English Proficiency

\begin{tabular}{|c|l|c|}
\hline No & \multicolumn{1}{|c|}{ Proficiency } & Average Score \\
\hline 1 & The teaching of speaking can improve my speaking performance & 3.6 \\
\hline 2. & I very frequently use English outside class time & 2.6 \\
\hline 3. & My speaking performance is good & 3.4 \\
\hline 4. & I have adequate vocabulary mastery for communication in general & 3.6 \\
\hline 5. & I have adequate vocabulary mastery for communication about library & 3.4 \\
\hline 6. & My English pronunciation is good & 3.4 \\
\hline 7. & $\begin{array}{l}\text { My English grammar is good, covering not only simple sentences but also } \\
\text { complex sentences }\end{array}$ & 3.2 \\
\hline & Average of total components: & 3.31 \\
\hline
\end{tabular}

Note:

The score results are interpreted as follows.

Score 5: very good

Score 4: good

Score 3: average

Score 2: fair

Score 1: poor

Data in Table 1 shows the students' perception on their English proficiency before learning with audio materials, which was close to good (3.31). It can be concluded that the teaching of speaking had an influence on students' speaking ability (item 1), while item 2 indicates that they rarely practiced English outside class. The scores from item 3 to item 7 (the indicators of speaking proficiency) shows that their proficiency was in the position of above average (3.4), but not yet close to good. The qualitative data collected by using open ended questions in the questionnaire were directed to find information on five aspects: their problems in learning English, their preferred types of learning activities, the media they like the most, and their suggestions to improve the quality of teaching English. Based on their answers, the results can be summarized as follows. The problems they face in learning to speak in general is fluency, accuracy, and vocabulary choice. Concerning types of learning activity, most of them like to have outside class activities and group work, but only one participant like teacher's explanation. The media they like the most is audio-visual; only one likes music (audio). Based on their problems and their preferences in learning, they suggest that the teaching 
of English be linked to their major area, and emphasized on activities they deal with in oral presentation tasks. They need feedback after presentation of topics on selected reading materials to make them understand the content of the materials in addition to feedback on language.

A questionnaire for the lecturers provides open-ended questions to get their opinion on 5 aspects: their perception on students' English proficiency, students' speaking ability, aspects of teaching English, recommended topics for students, and types of activities for learning English. Based on the responses, it reveales that according to the lecturers, the students' English general proficiency is fair, but their speaking ability is good. The recommended aspects in teaching English should include conversation, pronunciation practice, and vocabulary development. In terms of activities, student centeredness and conversation activities were recommended.

Based on the results of the needs analysis, the materials were developed starting from making a content map for the syllabus.

\subsection{Content map development}

On the basis of the data collected from the questionnaires responded by the students and the lectures, a conceptual review was done covering theories and empirical evidence of the validity of the materials in relation to the goal of the course. This was directed to find information and to make decision on what kinds of materials they needed: what language functions and which samples of expressions for natural communication would be selected. Those two important components were presented with a context of situation in the form of content map as shown in Table 2 [16].

Table 2. Speaking Materials Content Map

\begin{tabular}{|c|c|c|c|}
\hline Unit & Situation & Language Function & Expressions (Language features) \\
\hline 1 & $\begin{array}{l}\text { In a reception } \\
\text { desk. A new } \\
\text { foreign student } \\
\text { wants to become } \\
\text { a library member. }\end{array}$ & $\begin{array}{l}\text { Asking for and giving } \\
\text { assistance to foreign } \\
\text { visitors } \\
\text { Telling visitors how to } \\
\text { become a library } \\
\text { member. }\end{array}$ & $\begin{array}{l}\text { A: Good morning. Can I help you? } \\
\text { B: Yes, please. I am a new student here. Can you tell me } \\
\text { how to become a member? } \\
\text { A: Oh, sure. Please fill out this form, first. (after a } \\
\text { moment) OK? Wait for a minute (enter data in the } \\
\text { computer). Here you are (Giving a member card) } \\
\text { B: Thanks. Can I borrow a book now? } \\
\text { A: Sure. Go to the circulation desk over there. } \\
\text { B: Thanks } \\
\text { A; My pleasure }\end{array}$ \\
\hline 2 & $\begin{array}{l}\text { In a hall, } \\
\text { welcoming a } \\
\text { group of guests } \\
\text { from a foreign } \\
\text { university in } \\
\text { bench marking } \\
\text { program }\end{array}$ & $\begin{array}{l}\text { Describing library } \\
\text { service } \\
\text { (Monolog) }\end{array}$ & $\begin{array}{l}\text { Good morning ladies and gentlemen. Welcome to our } \\
\text { library. I'm going to describe our library service in this } \\
\text { university. } \\
\text { His library has } 10.000 \text { textbooks and } 450 \text { e-books and ect }\end{array}$ \\
\hline 3 & $\begin{array}{l}\text { In a deposit } \\
\text { room, a } \\
\text { conversation } \\
\text { between a guest }\end{array}$ & $\begin{array}{l}\text { Asking for and giving } \\
\text { directions }\end{array}$ & $\begin{array}{l}\text { A: excuse me. Where is the rest room? } \\
\text { B: Go straight ahead. Turn right at the corner of the } \\
\text { manager room. The toilet is on your left. } \\
\text { A: Thank you } \\
\text { B: Any time }\end{array}$ \\
\hline
\end{tabular}




\begin{tabular}{|c|c|c|c|}
\hline Unit & Situation & Language Function & Expressions (Language features) \\
\hline & $\begin{array}{l}\text { and a staff } \\
\text { member }\end{array}$ & & \\
\hline 4 & $\begin{array}{l}\text { In a seminar } \\
\text { room (speaking } \\
\text { in public) }\end{array}$ & $\begin{array}{l}\text { Presenting a topic in an } \\
\text { International } \\
\text { conference }\end{array}$ & $\begin{array}{l}\text { Good morning Ladies and Gentlemen. My name is } \\
\text { Wahyuni. I am from Jakarta National Library. } \\
\text { My topic is "How to develop an English program for } \\
\text { librarians as an in-service training. } \\
\text { Etc } \\
\text { The topic I want to talk about is how develop a }\end{array}$ \\
\hline 5 . & In a café & Introducing someone & $\begin{array}{l}\text { A: Hi Fina. This is Miss Firda. Miss Firda, this is Fina, } \\
\text { my staff } \\
\text { B: Hi } \\
\text { C: Hi }\end{array}$ \\
\hline 6 & $\begin{array}{l}\text { Lunch time in a } \\
\text { campus canteen } \\
\text { (a Conversation } \\
\text { between a library } \\
\text { manager and her } \\
\text { old friend }\end{array}$ & $\begin{array}{l}\text { Giving suggestions } \\
\text { Responding to } \\
\text { suggestions }\end{array}$ & $\begin{array}{l}\text { A: Your library is such an excellent place } \\
\text { B: Thanks } \\
\text { A: But, I think the rest room needs some more facilities } \\
\text { B: Such as? } \\
\text { A: Mmm it needs soap dispencer and sanitizer. } \\
\text { B: Oh, that's a good idea. What else do you suggest? } \\
\text { A: Perhaps, a bigger hand tissue holder. } \\
\text { B: OK. What a suggestion! Great. I'll make it done next } \\
\text { week. Thanks } \\
\text { A: My pleasure }\end{array}$ \\
\hline 7 & $\begin{array}{l}\text { In a circulation } \\
\text { room. } \\
\text { A conversation } \\
\text { between a } \\
\text { student and a } \\
\text { clerk }\end{array}$ & Making a request & $\begin{array}{l}\text { A: excuse me. I'm wondering whether you can extend the } \\
\text { due date. } \\
\text { B: Which book do you want } \\
\text { A: This one. Anthropology. } \\
\text { B: Oh, I'm sorry. We have only } 2 \text { copies, and there' s a } \\
\text { request today for this book. You can check it again next } \\
\text { week. } \\
\text { A: OK. No problem. Thanks }\end{array}$ \\
\hline 8 & $\begin{array}{l}\text { In a manager } \\
\text { room } \\
\text { An interview for } \\
\text { a position in a } \\
\text { library }\end{array}$ & $\begin{array}{l}\text { Performing a good } \\
\text { impression at a job } \\
\text { interview; responding } \\
\text { effectively in a job } \\
\text { interview }\end{array}$ & $\begin{array}{l}\text { A: Have a seat, Hafidz } \\
\text { B: Thank you } \\
\text { A: Well, mm our name is Hafidz } \\
\text { B: That's right } \\
\text { A: I'm interested in your CV. You have moved to three } \\
\text { different cities to work in a short contract. But why are } \\
\text { you interested in becoming a fulltime librarian? } \\
\text { B: I've check the reputation of this big library. Most of } \\
\text { the services are digitalized. But I'm sure I will be happy } \\
\text { working here. } \\
\text { A: But why? Are you sure you want this job? You have a } \\
\text { lot of experiences in assisting libraries to make it bigger, } \\
\text { and you are successful. } \\
\text { B: Yes. Definitely. Although this is a big library, I believe } \\
\text { I can make it bigger } \\
\text { A: Realyy? Can you explain it? }\end{array}$ \\
\hline 9 & $\begin{array}{l}\text { In a gazebo in the } \\
\text { front garden of a } \\
\text { library }\end{array}$ & $\begin{array}{l}\text { Casual conversation } \\
\text { (Meeting people) }\end{array}$ & $\begin{array}{l}\text { A: Morning Raf. Nice to see you again. } \\
\text { B: Morning. You, too } \\
\text { A: Are you doing an internship for this semester? } \\
\text { B: Yes. I'm preparing for it } \\
\text { A: Where? } \\
\text { B: in UB library } \\
\text { A: Wow. It's a big library. In which section are you going } \\
\text { to }\end{array}$ \\
\hline
\end{tabular}

Based on the content map, a draft of a speaking syllabus was developed in the form of competence-based syllabus in line with CLIL approach. The components cover the 
statement of competence standard, 9 basic competencies, materials/language functions, indicators, activities including assessment procedures, and time allotment. It was designed using the following format, but this example presents only two basic competencies. (The complete syllabus is not included in this article).

Competence Standard: The students are able to speak English for daily life and library services fluently, accurately, appropriately, and coherently at the intermediate level in many different kinds of situations such as meeting people in everyday situations, giving assistance to foreign visitors, responding to a complaint, describing library services, and many relevant situational conversations.

Table 3. Speaking Syllabus

\begin{tabular}{|c|c|c|c|c|}
\hline Basic competence & $\begin{array}{c}\text { Materials/Language } \\
\text { Functions }\end{array}$ & Indicators & Activities and Assessment & Time \\
\hline $\begin{array}{l}\text { Performing a } \\
\text { conversation in daily } \\
\text { interactions with } \\
\text { friends/colleagues }\end{array}$ & $\begin{array}{l}\text { Situation/Formal: between } \\
\text { boss and staff } \\
\text { S: Good morning Ma'am } \\
\text { B: Morning, Widya. You look } \\
\text { so messy. What happens? } \\
\text { S: I 'been running to come } \\
\text { here. I am coming by } \\
\text { Microlet (public transport) } \\
\text { B: sorry to hear that }\end{array}$ & $\begin{array}{l}\text { Use correct } \\
\text { expressions } \\
\text { Pronounce } \\
\text { English sounds } \\
\text { clearly }\end{array}$ & $\begin{array}{l}\text { In class: } \\
\text { Listening to a model of a } \\
\text { conversation. } \\
\text { (using audio speaking } \\
\text { materials) } \\
\text { Practice a conversation. } \\
\text { Make their own } \\
\text { conversation based on a } \\
\text { given situation. } \\
\text { Assessment: observing } \\
\text { students' practice and } \\
\text { giving feedback on } \\
\text { pronunciation, grammatical } \\
\text { accuracy, and fluency. } \\
\text { It can be done through } \\
\text { Edmodo or face-to face in } \\
\text { the classroom. }\end{array}$ & $\begin{array}{l}3 \mathrm{~h} \\
\text { (credit } \\
\text { hour) }\end{array}$ \\
\hline $\begin{array}{l}\text { Describing a library } \\
\text { service (etc) }\end{array}$ & & & $\begin{array}{l}\text { Before class: } \\
\text { Online learning }\end{array}$ & \\
\hline
\end{tabular}

The format begins with competence standards, and the syllabus contains 5 columns covering the components of basic competence, materials, indicators, and time allotment. One-semester activities contain 16 weeks, but since the midterm assessment is done in the middle of the semester (after Unit 5), and the final assessment is scheduled in the end of the semester (week 16), so the effective meeting was 14 weeks.

Based on the syllabus, the speaking materials were developed in the form of audio materials and a module for classroom activities. The module contains conversation practice, grammar, and vocabulary exercises. Some of the audio materials can be used in the classroom for practice while some others are accessed in Edmodo for outside classroom activities (online). In addition, speaking assessment was developed for formal assessment (the midterm assessment and final assessment) that comprises a speaking prompt and a holistic scoring rubric. The materials were then implemented to 8 volunteers of target learners. Group interview was done to find data on the students' perceptions of the implementation of the materials.

In the group interview after implementation, the respondents stated several advantages of the speaking materials. Using audio materials in the blended learning 
activities were suitable for their need and convenience. They were able to practice speaking any time without time constraints, the module helped them learn grammar for accuracy, and they could discuss their work and/or ask for explanation in the classroom. They found it interesting to learn from the samples of conversation and presentation, which were helpful in helping them speak more accurately especially in pronunciation. Last but not least, they found it motivated to learn from the recording when they realized that the conversations were performed by Indonesian learners (senior students of the English Department). The audio speaking materials showed that the English conversation was so perfect like native speakers that inspired them to learn better. In addition to their positive responses, they gave suggestions for activities of topic presentation. They would like to get feedback not only in terms of the content knowledge of the topic but also the accuracy and fluency of their English.

\subsection{Discussion}

The audio materials were made in response to the need of the Library Science Department students for a speaking class by following a systematic procedure. The consideration of choosing suitable language functions made them motivated to learn. This is evidence of how language instructions which are suited with learners' major and interests would be meaningful for them and would make them enjoy learning. The materials contain authentic communication as suggested by Johnson [17]. So, the activities engage students in the use of the target language in the "real world." Implemented in a blended learning format, the online activities gave advantages because time constraints were solved. Also, learners benefit from the dual focus forms of instruction: learning the language and the content of their major [18]. So, language use and language learning are connected. In this case, since the goal is teaching students to use English for effective communication, the emphasis is on "language teaching" rather than "content teaching." Dale and Tanner believe that CLIL helps learners to learn a new language more efficiently than in separate language lessons [19]. Concerning arousing motivation, the finding of this study is similar to Liu's experimental research where she found that English classes using ICT-based media was able to change learning atmosphere from a "have to learn" into "like to learn" situation [20].

CLIL looks similar to Content-Based Language Teaching (CBLT). CLIL basically focuses on teaching a subject matter through a language, as a dual focus, whereas CBLT focuses on teaching language by accommodating the content of the subject matter knowledge that the learners learn (their major) to make it more meaningful and useful for them. This comes from the believe that teaching dual focus (subject matter and language) can be done in an integrated manner, that is to say, the subject is better learned through the new language rather than teaching the language separately [19]. So, the starting point and the emphasis are a bit different. In the Library Science Department, the learners need to learn how to become a good librarian through content knowledge courses and at the same time they have to develop their oral competence in using English for library services. So, CLIL is suitable for them. While Khranke focuses on the teaching of language by integrating content that the learners need, CLIL is a bit 
more flexible whether it is teaching content through language or teaching language by accommodating content knowledge of the students [4]. It can be both basically.

In the implementation, BL can accommodate the necessary variation in learning formats that meets the learners' need [21]. In addition, providing learning resources and various learning experiences in a conducive learning environment can give opportunities to the learners to interact and build knowledge and skills optimally [22]. Feedback in the learning process can be given not only by the teacher but also by their peers.

Basically, assessment for the speaking class can be both assessment for learning in the form of feedback, and assessment of learning, or achievement assessment to measure their speaking achievement [23]. Assessment is a systematic procedure to identify whether learning takes place [24], so, in the implementation of this audio speaking materials, giving corrective feedback is indispensable to help learners improve their skill as assessment for learning, and to identify achievement is done by measuring students' speaking performance using a scoring rubric. Both online and faceto-face direct feedback in the blended learning is part of the learning activities that helps a lot in developing speaking skill.

\section{Conclusion}

In reference to the product of this study, the audio speaking materials, supported with a module, and implemented in a blended learning format are suitable for developing students' speaking ability. The language functions with the selected libraryrelated theme for activities are contextually relevant to learners' need and beneficial for three reasons. Firstly, and most importantly, the speaking activities are selected to meet their need for future profession and daily life. Therefore, it is "authentic" in nature as it reflects "real" communication. Secondly, the combination between face-to face and online learning makes the learning more practical because learners can manage their own time of learning outside class at their convenience. It can also accommodate different pace of learning, and functions as independent learning materials. Both teacher assessment (achievement assessment) and peer assessment (assessment for learning) can be done in a flexible format; offline in the classroom and online outside the classroom. Finally, such blended learning is more interesting and motivating compared to just face-to face with written dialogs to learn in a conventional classroom.

In reference to the findings, suggestions are directed to the lecturers, students, and future researchers. The lecturers are suggested to monitor the online learning activities to make sure that learners are on task as expected. The classroom activities are focused more on giving feedback for accuracy, fluency, and pronunciation. In doing the tasks, the students are encouraged to present their reflection orally so that they can practice speaking for authentic purposes, and at the same time they can solve their problems. Future researchers are suggested to make other speaking materials with different theme and language functions to enrich broader situations in speaking. The research results served as evidence of the advantages of the audio speaking materials. These innovation products provide a complete set of teaching learning materials covering competence- 
based CLIL syllabus, audio Speaking materials accompanied with a module for activities for students in more innovative leaning activities, and a speaking assessment instrument consisting of a speaking prompt and a holistic scoring rubric. The product can be used by students of Library Science Department as a pre-service English training and by librarians as in-service training.

\section{$5 \quad$ References}

[1] Library Science Study Program, Library Science Curriculum, Faculty of Letters, UM. Malang: Universitas Negeri Malang, 2014.

[2] G. Dudeney and N. Hockly, how to teach English with technology, 2. impr. Harlow: Longman, Pearson Education, 2007.

[3] S. Grayston and H. Smith, "Professional Development for ELT, CLIL and Content Teachers.," presented at the Paper presented at RELC International Conference, Singapore, 2015.

[4] K. J. Khranke, Approaches to Syllabus for Foreign Language Teaching. New Jersey: Prentice-Hall Inc, 1987.

[5] F. Mishan, Demystifying Blended Learning. In Tomlinson, B. (Ed.). (2013). Developing Materials for Language Teaching. London: Bloomsbury Publishing, 2013.

[6] N. F. Tungka and N. Mukminatien, “The Investigation of EFL Students' Experiences, Skills and Preferences in Reading Multimodal English Medium Texts | TESOL Indonesia 2016 Conference," 2016.

[7] R. P. Yaniafari and N. Mukminatien, "DEVELOPING MULTIMEDIA-BASED LISTENING MATERIALS FOR 1ST GRADE STUDENTS OF SMK,”p. 9, 2012.

[8] R. P. Yaniafari, "Developing Listening Courseware as Suplementary Materials for Listening II Course in Unisma," DISERTASI dan TESIS Program Pascasarjana UM, vol. 0, no. 0, Jul. 2014.

[9] E. Bañados, "A Blended-learning Pedagogical Model for Teaching and Learning EFL Successfully Through an Online Interactive Multimedia Environment," CALICO Journal, vol. 23, no. 3, pp. 533-550, 2006. https://doi.org/10.1558/cj.v23i3.533-550

[10] T. Miyazoe and T. Anderson, "Learning Outcomes and Students' Perceptions of Online Writing: Simultaneous Implementation of a Forum, Blog, and Wiki in an EFL Blended Learning Setting," System: An International Journal of Educational Technology and Applied Linguistics, vol. 38, no. 2, pp. 185-199, Jun. 2010. https://doi.org/10.1016/j.system. $\underline{2010.03 .006}$

[11] K. Graves, Designing language courses: a guide for teachers, Nachdr. Boston: Heinle \& Heinle, 2007.

[12] D. Finney, "The ELT Curriculum: A Flexible Model for a Changing World. In Richards, J. C. \& Renandya, W. R. (Eds.). 2002. Methodology in Language Teaching.," Cambridge: Cambridge University Press., 2002. https://doi.org/10.1017/CBO9780511667190.012

[13] K. Shumin, "Factors to Consider: Developing Adult EFL Students' Speaking Abilities," Forum, vol. 35, no. 3, 1997.

[14] M. Canale and M. Swain, "THEORETICAL BASES OF COMMUNICATIVE APPROACHES TO SECOND LANGUAGE TEACHING AND TESTING," Applied Linguistics, vol. I, no. 1, pp. 1-47, Jan. 1980. https://doi.org/10.1093/applin/I.1.1

[15] I. McGrath, Materials evaluation and design for language teaching, Second edition. Edinburgh: Edinburgh University Press, 2016. 
[16] N. Mukminatien, "Developing Life-Based Speaking Syllabus for Librarians in a Blended Learning Format," presented at the Paper Presented at ICLI International Seminar, on 4th October 2017, Malang: Universitas Negeri Malang, 2017. https://doi.org/10.2991/icli17.2018 .29

[17] E. B. Johnson, Contextual teaching and learning: what it is and why it's here to stay. Thousand Oaks, Calif: Corwin Press, 2002.

[18] D. Coyle, P. Hood, and D. Marsh, CLIL: content and language integrated learning. Cambridge, UK; New York: Cambridge University Press, 2010.

[19] L. Dale and R. Tanner, CLIL activities: a resource for subject and language teachers. New York; Cambridge: Cambridge University Press, 2012.

[20] J. Liu, "An Experimental Study on the Effectiveness of Multimedia in College English Teaching," 2010. https://doi.org/10.5539/elt.v3n1p191

[21] K. Thorne, Blended learning: how to integrate online \& traditional learning. London; Sterling, VA: Kogan Page, 2003.

[22] A. Littlejohn and A. Pegler, Preparing for Blended e-Learning. London: Routledge. Taylor and Francis Group English Teaching, 2007. https://doi.org/10.4324/9780203961322

[23] L. Lee, "Evaluating Intermediate Spanish Students' Speaking Skills through a Taped Test: A Pilot Study," 2000. https://doi.org/10.2307/346151

[24] H. D. Brown, Language assessment: principles and classroom practices, Nachdr. New York: Longman, 2006.

\section{Authors}

Nur Mukminatien is a professor in English Language Teaching at Universitas Negeri Malang, East Java, Indonesia. Her interest in teaching and research is Writing. She has actively participated in Teacher Certification Program as a national trainer for pre-service and in-service teacher training. Email: nurmukminatien.fs@um.ac.id

Rahmati Putri Yaniafari is an academic staff member at the Department of English, Universitas Negeri Malang. She has a keen interest in English Language Teaching, especially Autonomous Learning, Computer Assisted Language Learning (CALL), and CLIL (Content and Language Integrated Learning). Email: yaniafari.fs@um.ac.id

Taufiq Kurniawan is an academic staff of Library Science Study Program, Universitas Negeri Malang. He earned his master degree in Library Science from Sunan Kalijaga State Islamic University Yogyakarta, Indonesia. His research interests are in Digital Library, Information Retrieval System, and Information Literacy. Email: taufiq.kurniawan.fs@um.ac.id

Agung Wiradimadja is an academic staff of Social Studies Study Program Universitas Negeri Malang. He is interested in social studies, education and learning innovation. Email: agung.wiradimadja.fis@um.ac.id

Article submitted 2020-01-19. Resubmitted 2020-02-13. Final acceptance 2020-02-16. Final version published as submitted by the authors. 